\title{
Virus-associated trichodysplasia spinulosa
}

INSERM

\section{Source}

INSERM. (1999). Orphanet: an online rare disease and orphan drug data base. Virusassociated trichodysplasia spinulosa. ORPHA:228379

Virus-associated trichodysplasia spinulosa is a rare infectious skin disease characterized by the development of follicular papules with keratin spicules in various parts of the body, predominantly in the face (e.g. nose, eyebrows, auricles), that is due to polyomavirus infection in immunocompromized patients. 